\title{
Boettke, The Austrian School and the Reclamation of Reality in Modern Economics
}

\author{
PAUL LEWIS
}

pal1002@hermes.cam.ac.uk Faculty of Economics and Politics, Faculty of Social and Political Sciences, and Selwyn College, Cambridge University, $U K$

\begin{abstract}
In a series of recent papers, the prominent Austrian economist Peter Boettke has criticised orthodox economics for its lack of realism. This paper situates Boettke's critique in the context provided by recent developments in the methodology of economics, most notably critical realism. While there is a good deal of common ground between Boettke's approach and critical realism, the latter also helps to reveal some of the limitations of the variant of Austrian economics to which Boettke subscribes. Suggestions are made as to how critical realists and Austrians such as Boettke might move forward together in developing a more realistic, relevant and fruitful approach to economic analysis.
\end{abstract}

Key Words: Austrian economics, ontology, realism, power

JEL classification: $\quad$ B0, B2, B4.

\section{Introduction}

'No reality, please. We're economists!' This phrase, taken from a recent edition of the education supplement of The Times newspaper, encapsulates a widely held belief that modern academic economics has become increasingly detached from the real world. ${ }^{1}$ The discipline of economics, so its detractors maintain, is dominated by exercises in formal modelling that are designed more to showcase the technical virtuosity of economists than to illuminate pressing economic problems.

A variant of this line of argument has recently been developed in a number of papers written by the prominent Austrian economist Peter Boettke. ${ }^{2}$ At the heart of Boettke's critique lies the claim that the tools utilised by orthodox economists-notably formal mathematical modelling-are unsuitable for the analysis of the socio-economic world. For Boettke, the language of mathematics constitutes a Procrustean bed that is unable to do justice to many of the essential features of socio-economic reality, the consequence of which is that formal mathematical models are so far divorced from the realities of socio-economic life that they unable to address, let alone provide answers to, many of the questions that have traditionally been regarded as central to economics. Only if economists tailor their methods more closely to the nature of their subject-matter-in particular by displaying a greater willingness to express their theories discursively, in natural language, as opposed to the mathematical language of formal modelling-will the realities of economic life be re-engaged and the discipline be in a position once again to make significant progress. 
Boettke's work has provoked a vigorous response from defenders of orthodox economics. ${ }^{3}$ The purpose of this paper is to contribute to the debate initiated by Boettke by situating it within the context provided by recent developments in the methodology of economics. Economic methodologists, having previously focused almost exclusively upon the epistemological issues involved in the development and appraisal of economic theories, have in the past decade or so begun to devote considerable attention to the ontological commitments of those theories, that is, to what they presuppose about the nature of the socio-economic world. In the vanguard of this 'ontological turn' in the methodology of economics is an approach known as critical realism. This approach, which has received its fullest statement to date in Tony Lawson's Economics and Reality (1997), claims that a prerequisite for fruitful social scientific research is a set of analytical tools that are tailored to suit the nature of the socio-economic material under investigation. Like Boettke, then, critical realists believe that if economics is to be successful, it requires 'an anchor in the real world' (Boettke 1996:34). To this end, critical realists use philosophical arguments to develop an abstract picture of the nature of the socio-economic world, which is then used to inform an account of the methods appropriate for studying socio-economic life. This line of reasoning leads critical realists to concur with Boettke that the methods employed by mainstream economists enjoy a distinctly limited applicability in the socio-economic world.

The objective of this paper is to show that there is a good deal of common ground between Austrians and critical realists, and that as a result there exists considerable scope for a mutually beneficial exchange of ideas between proponents of the two approaches. The structure of the paper is as follows. Section 2 sets out Boettke's critique of orthodox economics, after which (in Section 3) his preferred approach to economic analysis is outlined. Critical realism introduced in Section 4 of the paper. While the fourth section of the paper emphasises the commonalities between critical realism and the version of Austrian economics espoused by Boettke, Section 5 draws attention to what from a critical realist vantage point appears to be a potentially important limitation of Boettke's position, before going on to suggest how critical realism can help to overcome it. The final section of the paper summarises the argument and suggests how the critical realism and Austrianism might move forward together in an attempt to develop a more realistic, relevant and fruitful approach to economic analysis.

\section{Boettke on Modern Economics and the Flight from Reality}

Central to Boettke's critique of orthodox economics lies the claim that the analytical apparatus employed by orthodox economists for the production of knowledge about the socioeconomic world - notably, formal mathematical modelling — is in fact singularly ill-suited to its allotted task:

'My hypothesis is that economics made a fateful choice in the 1930s and 1940s and chose an intellectual developmental path which has generated a bifurcation in economic thinking between theoretical systems and the real world those systems are supposed to represent, a bifurcation not easily repaired. Formalistic precision was (and is) followed, and the cost was 
(and is) a loss of relevance of the discipline of economics for the messy world in which we live. Even on the empirical front, fine estimation techniques were developed, but the richness of the empirical world remains hidden from scientific view. Theoretically and empirically, I assert, the technology chosen for the task at hand led (ex post) to an intellectual dead-end' (Boettke 1996:22-23).

Boettke (1996:24-27) contends that the dictates of formal modelling (in particular the quest for determinate solutions) have led orthodox economists to adopt a plethora of simplifying assumptions designed to eliminate various sources of indeterminacy from their models and so render them mathematically tractable. An unfortunate consequence of this approach, Boettke argues, is that it has led orthodox economists to exclude from their models a number of features of socio-economic life which, although of paramount importance, cannot easily be expressed using the language of mathematics:

"My point is simply to suggest that the "medium" is the message, so to speak. The language of modern economics, due to the demands for determinacy, crowds out questions of subjective assessment, institutional context, social embeddedness, knowledge (as opposed to information), judgement, entrepreneurship, creativity, process and history (see Samuels 1989[a])' (Boettke 1996:27, Boettke 1997:17, 49-50).

Perhaps most notably, orthodox economists' preoccupation with formal modelling, and the need for mathematical tractability which follows in its wake, has led them to adopt a highly distorted picture both of the behaviour of economic agents and also of the conditions or 'problem situation' within which they act. Specifically, the demand for determinate solutions has motivated a portrayal of homo economicus as facing a known means-ends framework that uniquely determines his or her behaviour. Such an account is a far cry from the world of uncertainty and utter ignorance that confronts real-world economic agents and leaves little scope for the exercise of the entrepreneurial imagination or, indeed, anything else involved in the exercise of genuine human choice (Boettke 1996:27, 29, 34-35, 1997:20, 49).

The upshot of the orthodoxy's determination to frame its arguments within a mathematical dialect, Boettke argues, is that mainstream economics has become so divorced from the real world it purports to investigate that it is incapable even of addressing, leave alone of answering, questions which have long been regarded as central to the discipline of economics. The orthodoxy's analysis of the coordinating powers of the price mechanism is a case in point. The question of whether it is possible for the activities of self-seeking economic agents in a decentralised economy characterised by dispersed knowledge to yield an orderly disposition of resources has a good claim to be the central concern of economics (Hayek [1937] 1948:50). In order to bring the orthodox analysis of rational conduct to bear on this issue, it is of course necessary to model each agent as facing a known mean-ends framework. However, given that the factors which affect the outcome of one agent's conduct include the actions of other individuals, the only way that the requirements of the orthodox approach can be met is by considering equilibrium states, that is, situations where the prevailing market prices induce agents to form plans which are pre-reconciled in the sense that each agent's decision correctly anticipates and is compatible with the various courses of action which the other agents intend to pursue (Shackle [1972] 1992:53-54, 90-91, 104, 124). Orthodox economists claim that by constructing a model economy for which there 
exists such a set of equilibrium prices, they have demonstrated that it is logically possible for the pursuit of private self-interest, guided only by market prices, to be consistent with an orderly outcome (Arrow and Hahn 1971:1, Hahn 1984: 86, 114, 308-309, Geanakoplos 1987:119, Milgrom and Roberts 1992:58).

However, as Austrians since Hayek ([1937] 1948, [1945] 1948a) have argued, the strategy of concentrating analytical attention on situations in which a set of equilibrium prices has already been established begs rather than answers the question of how to account for the coordinating power of the price mechanism because it fails to explain how such equilibrium prices are generated in the first place (Hayek [1937], 1948:46, 51). An approach centred on the analysis of those states of affairs where people's plans are pre-reconciled and so informed by (at least a probabilistic) knowledge of other agents' conduct cannot be used to explain how actions are brought into ever closer conformity with one another in situations where, owing to the importance of the knowledge of the particular circumstances of time and place, their knowledge of one another's intentions is so scanty that it does not admit even a probabilistic rendering. Indeed, it is hard to see how things could be otherwise with orthodox economics, for the assumption which underpins the orthodox approach, namely that rational conduct proceeds by the application of reason to known circumstances, excludes by fiat the epistemic problem of how agents acquire the knowledge of a hitherto unknown meansend framework required to enable them to adjust prices towards their equilibrium values (Boettke 1996:33, 36 n. 4, 37 n. 13, Shackle [1972] 1992:447). The conclusion that Boettke draws from this lacuna in the orthodox approach is that the latter 'should be understood as an abandonment of the main intellectual quests of economic science since Adam Smith: the explanation of how individual behaviour influencing price adjustments generates an overall order that tends to coordinate the decisions of the most willing suppliers with those of the most willing demanders. Equilibrium theories ... do not explain the activity that brings the situation [of order] about, but rather simply postulate the point so derived' (Boettke 1996:31, also see Boettke 1996:27, 30-31, 1997:25, 49-50, 54 n. 16, 17, 1998, 179, 180, 184 n. 5; Boettke and Prychitko 1998:ix-xiii, xix).

For Austrians, then, the price that orthodox economics must pay for its preoccupation with formal modelling is a lack of relevance for the study of the real world economic problems, including those (such as the coordination of economic activity) which provide the discipline of economics with its raison d'être. The orthodox approach systematically excludes the very features of the socio-economic world that give rise to those problems and is therefore incapable of providing a satisfactory analysis of them. As a result, orthodox economics is condemned to remain confined to the realm of pure logic (Hayek [1937] 1948:33, 44), investigating the properties of fictional model-economies so far removed from the real world that any results derived from analysing them are of distinctly limited applicability to the real empirical world (Boettke 1996:23-27, 30-31, 33-34, 1997, 22, 48-50, 1998:180, 183, 1999:xxiv).

\section{The Austrian Approach: The Discursive Analysis of the Market Process}

If economics is to become more productive in advancing our understanding of fundamental issues such as the coordinating power of markets, then, according to Boettke, orthodox 
economists must display a far greater willingness to tailor their analytical tools to suit the nature of problem under investigation. In particular, rather than insisting that theories be expressed in a mathematical dialect whose emphasis on determinate solutions (at its current stage of development at least) precludes consideration of the very factors (such as uncertainty and creative choice) that are definitive of the problem of social order, economists should aim to do justice to the open-ended (and so uncertain) nature of socio-economic life by framing their theories discursively, in natural language. A reallocation of the discipline's intellectual resources away from formal mathematical models towards a more discursive mode of theorising will enable economists to acknowledge the real epistemic problem faced by economic actors whose beliefs about the possible consequences of their actions are invariably subjective, incomplete, partial, vague and even on occasions (and viewed with the benefit of hindsight) just plain wrong. This will in turn facilitate the study of the real problem of social order, namely the question of 'how the spontaneous interaction of a number of people, each possessing only bits of knowledge, brings about a state of affairs in which prices correspond to costs, etc., and which could be brought about by deliberate direction only by somebody who possessed the combined knowledge of all those individuals (Hayek [1937] 1948:50-51) (Boettke, 1997:50-51, 1998:1974-1975, 178, 182183).

Accordingly, the analysis of the problem of social order to which Austrian economics gives rise proceeds by way of discursive analyses of various aspects of market economies concerned with the acquisition and dissemination of knowledge. A rich and varied programme of research has emerged, the central theme of which is that the market should be viewed as a process of discovery driven by the agency of entrepreneurs and embedded within networks of economic and non-economic institutions (Boettke and Prychitko 1998:ix-x, xv-xvi). ${ }^{4}$ The prime movers of the process are the entrepreneurs, economic agents who are alert to the opportunities for profit afforded by disequilibrium prices and who are induced by the prospect of those profits to alter their behaviour so that it is more in tune with the prevailing technological and market possibilities. The market process, on this view, is a process of mutual learning whereby, in the course of exploiting hitherto unnoticed opportunities for profit, entrepreneurs systematically revise their plans in order to bring them closer into line with the intentions of their fellow market participants, thereby contributing towards the development of an orderly outcome (Kirzner 1992:41-51, 132-133, 146, 159-161, 2000:5, 11-20, 225-227, Boettke 1997:25-27, Boettke and Prychitko 1998: xix).

The epistemic problem faced by real-life economic agents - the fact that often they are ignorant of many of the factors which influence the outcome of their decisions and so often possess only the haziest notion of the consequences of their actions-is both a cause and consequence of the discovery process (Runde, 2002). Radical uncertainty is a condition of the discovery process because in its absence there would be no reservoir of hitherto unforeseen profit opportunities and so nothing to fuel the entrepreneurial alertness, boldness and imagination that keep the market process in motion. The epistemic problem is at least in part also a consequence of the discovery process. The creative exploitation of profit opportunities by entrepreneurs is itself something that shapes the future in surprising ways, rendering some people's original expectations erroneous and prompting them to revise 
their plans. This process of plan revision generates new profit opportunities and thereby offers scope for fresh rounds of entrepreneurial activity (Kirzner 1992:12-13, 19-36, 41-51, 93-94, 245-248, 2000:17-20, 60-65, Boettke 1997:27).

Austrians have also observed that a variety of social devices (social institutions, rules, conventions, and so forth) have developed in order to help actors cope with their (solipsistic) ignorance of the future. When it comes to interpreting the significance of disequilibrium prices, for example, economic actors are able to transcend the confines of their own partial and subjective viewpoint by relying on shared cognitive frameworks and interpretative schemes. The existence of such widely accepted frameworks of understanding enables agents to reach common or intersubjectively agreed interpretations of the meaning and significance of price signals, thereby increasing the likelihood of their developing plans which are mutually compatible (Lachmann 1971, Ebeling 1986, 1987, 1990, Boettke 1990a, 1990b, Fleetwood 1995:125-155, O'Driscoll and Rizzo 1996:32, 39-40, 105-106). Furthermore, institutions have also evolved which empower economic agents to deal with situations where, notwithstanding the shared interpretative frameworks alluded to above, they have been surprised by unforeseen developments. Money, which provides people with the liquidity required to respond to unexpected obligations and opportunities, constitutes one example of such an institution. A second is to be found in the legal system which, by ensuring that long-term contracts are enforced, helps to furnish economic agents with a degree of assurance about the future (Rizzo 1996:xxvixxix). The perceived significance of such social devices for the achievement of social order has persuaded a number of Austrians to distance themselves from what they see as the atomistic individualism of orthodox economics in favour of a phenomenologicallyinformed view of man as a social being negotiating a world of intersubjectively-agreed meanings (Boettke 1996:32, Vaughn 1994:130, 132-133). ${ }^{5}$ We shall return to this point below.

The picture of the market sponsored by the Austrian vision, then, is one of a process of continuous change, situated within a nexus of economic and non-economic institutions and kept in motion by the creative responses of economic agents to the changes in knowledge precipitated by unforeseen contingencies and the consequent need for plan revision. The discipline of economics, on this view, has two intertwined objectives: first, to provide causal explanations of how the purposive activities of economic agents generate changes in prices, outputs, methods of production and the allocation of resources, and so generate an orderly outcome (Mayer [1932] 1994, Cowan 1994, Cowan and Rizzo 1996, Boettke 1999:xxiv); ${ }^{6}$ and, second and relatedly, to highlight and explore the social devices which make possible the coordination of such activities in decentralised market economies (Boettke 1989:78, 1996:27-28, 32, 1997:35, Boettke and Prychitko 1998:x, xiii, xv-xvi, xix, xxi-xxii). The view of economics which emerges from the Austrian approach has been summarised as follows:

'Economics in the hands of Austrians emerges neither as a quantitative science of exact prediction nor a mathematical system of exact determination, but rather a qualitative science of tendency and direction expressed in a verbal logic of cause and effect.' (Boettke and Prychitko 1998:xx; also see Boettke 1994:605). 


\section{The Ontological Turn in Economic Methodology: Critical Realism and its Affinities with Austrian Economics}

I want now to consider Boettke's critique of orthodox economics, along with the Austrian school's preferred approach to economic analysis, in the light of recent developments in economic methodology that have come to be known by the name of critical realism. The present section of the paper will be devoted to the task of staking out the common ground between critical realism and Austrian economics on important issues of methodology, ontology and epistemology. The following section will attempt to suggest how critical realism can help Austrians such as Boettke to develop their insights into the working of the socio-economic world.

The positions that critical realists and Austrians such as Boettke adopt on fundamental issues of methodology, ontology and epistemology share a good deal in common. We shall consider each of them in turn, beginning with the issue of methodology. Central to critical realism is the claim that successful substantive research requires a methodology that is tailored to suit the nature of the material under investigation. As critical realists define the term, a methodology is 'well-tailored' to its subject-matter if it satisfies two-criteria. First, the analytical tools and mode of explanation sponsored by the methodology in question should not give rise to such a distorted account of the phenomenon under investigation that theorists are compelled to invoke fictional entities (such as perfectly competitive firms, agents possessing rational expectations, and the like) which are conspicuous by their absence from the real world. Critical realists are methodological realists, advocating the use of methods that do not require researchers to employ convenient fictions in their theories. ${ }^{7}$ The second criterion that a methodology must satisfy if it is to counts 'well-tailored' to its subjectmatter in the eyes of critical realists is that it should not lead researchers systematically to ignore potentially explanatorily significant features of the socio-economic world, that is to say features which might on occasion play a major part in accounting for the occurrence of some economic phenomenon of interest.

So, how does the methodology of modern Austrian economics fare when judged according to these two criteria? It will be argued immediately below that Austrian economists like Boettke set great store by the first criterion and so share with critical realism a commitment to methodological realism. However, as we shall see in the next section of the paper, the vantage point provided by critical realism suggests that the Austrian school fares less well when it comes to the (second) issue of whether its preferred methodology leads researchers systematically to ignore potentially explanatorily important aspects of socio-economic life.

Austrians like Boettke share with critical realists a commitment to methodological realism. For instance, Boettke (1997:35) argues that rather than studying imaginary worlds in which agents enjoy at least a probabilistic knowledge of the consequences of their actions, economists should examine "how imperfect human beings attempt to cope in the real world of ignorance and uncertainty':

'If what we demand out of an economic theory is realism, then Austrian economics strives to deal seriously with the real social conundrum in which human actors are placed ... [I]f one is to deal with the everyday world in which human beings live, then one must not distort their situational environment beyond recognition simply for formal tractability. If the tools 
are not flexible enough to deal with the problem, then rather than turning away from the problem, perhaps it is time to choose new tools of analysis. Seriously grappling with the implications of time and ignorance, rather than ever more refined exercises in constrained optimization, may provide the foundation for a humanistic (yet logically sound) and policyrelevant economics' (Boettke 1996:32, 1997:35, Boettke and Prychitko 1998:ix).

Far from concentrating analytical attention on a 'fictitious homo oeconomicus,' Mises (1949:64-65) writes, Austrian economics 'aims to know reality':

'Economics deals with the real actions of real men. Its theorems refer neither to ideal nor to perfect men, neither to the phantom of a fabulous economic man (homo oeconomicus) nor to the statistical notion of an average man (homme moyen). Man with all his weaknesses and limitations, every man as he acts and lives, is the subject of catallactics' (Mises 1949:651; quoted in Boettke 1990a:18; also see Hayek 1948b:8-13, Boettke, Horwitz and Prychitko 1994:70). ${ }^{8}$

Of course, if critical realists contend that economists should tailor their analytical tools and modes of explanation to suit the character of their subject-matter, then it is incumbent upon them to provide an account of the nature of the socio-economic world that can be used to inform attempts to identify the most appropriate methods of research. To this end, critical realists have used philosophical arguments to develop an abstract picture of the nature of socio-economic reality, which then forms the basis for an attempt to characterise the methods that are suitable for investigating the socio-economic world. The account of the nature of socio-economic reality - the particular variety of ontological realism - to which critical realists subscribe has a good deal in common with the Austrian school's view of the socio-economic world, although, as we shall see later in the paper, there remain some significant differences between the precise social ontologies to which the they subscribe.

Critical realists argue that the socio-economic world can be divided into three ontologically distinct realms: the actual (actual states of affairs and events, including the actions and practices of economic actors); the empirical (our sensory experiences of those events and states); and the domain of underlying social structures, which (as we shall see in due course) facilitate and constrain the activities of economic agents. These three realms are ontologically distinct from each other. In critical realist parlance, the socio-economic world is described as being structured. In adopting this metaphysics, ${ }^{9}$ critical realists seek to avoid the polar extremes of voluntarism (according to which social structure is the mere creation of, and so is reducible to, human agency) and determinism (which portrays human agency as totally determined by, and so reducible to, social structure). In contrast to such extremes positions, critical realists argue that human intentional agency and social structure as best understood as being recursively related: each is both a necessary condition for, and also a consequence of, the other. More specifically, and as will be explained in greater detail below, social structure and intentional human agency interact with one another over (historical) time, with people continuously draw upon (pre-existing) social structures in order to act, with their behaviour leading (subsequently) either to the reproduction or the transformation of those structures.

The point of departure for the argument by which critical realists justify this picture of the socio-economic world is the ex posteriori observation that there is a paucity of stable event regularities in the socio-economic world. (An event regularity is a pattern of the form: 
'Whenever event or state of affairs $x$, then event or state of affairs $y$ '.) Those circumstances in which such regularities obtain are termed closed systems; those in which regularities are absent are described as being open. The failure of generations of econometricians in finding much in the way of sharp and enduring event-regularities is taken by critical realists as the most notable piece if evidence for the openness of the socio-economic world (Lawson 1997:70, 1998:357-360). Critical realists argue that the principal explanation for the openness of the socio-economic world resides in the reality of human choice. Critical realists concur with Austrians that the powers of the active human mind-more specifically, its qualities of imagination, creativity and boldness-imply that the course of action a person chooses to pursue is not simply a determinate or single-exit response to her external environment. On the contrary, choice is an open-ended enterprise such that if in any given circumstances $(x)$ a person chose to do $y$, then (s)he could have chosen to undertake some other course of action (not- $y$ ). In other words, genuine choice presupposes that the socioeconomic world is an open system. And it is the reality of human choice that explains the paucity of sharp, stable event regularities in socio-economic life (Lawson 1997:8-11, cf Boettke 1990a:18, 1990b:60-1, 1996:27, 1997:20, Buchanan [1969] 1979:39-52, Kirzner 2000:8, 55-65).

Critical realists extend this line of argument by arguing that if a person's actions are indeed chosen, then it must be possible to give an account of them in terms of that person's beliefs and desires; that is, human action must be intentional under some description. Now, as critical realists see things, intentional agency is possible only if the actors in question have some idea about how to achieve their goals. For, as Austrians such as O'Driscoll and Rizzo (1996:76) and Shackle (1966:74, 107, 1969:4-5) have observed, if people are so ignorant about the future that they are utterly incapable of discerning any connection between their decisions and the ensuing outcome, then purposeful human action would be impossible. The question that naturally arises from this line of reasoning is as follows: What is the source of the knowledge that informs the decisions taken by economic actors? The fact that the socio-economic world is an open system implies that the objects of such knowledge cannot be event regularities. Rather, the relevant objects of knowledge must be non-empirical (Lawson 1997:30-31). More specifically, the vantage point provided by critical realism suggests that peoples' actions are informed and guided by their understanding of (nonempirical) social structures (social rules and institutions). For example, long-term contracts are a social institution that enables economic actors to secure a degree of control over their future income and expenditure (in the case of households) and revenues and costs (in the case of firms), thereby providing them with a measure of assurance about the future. While such contracts do not tie the future down completely, and so do not give rise to stable event regularities (there always remains the possibility, sometimes realized, that one of the parties will unexpectedly renege on their contractual commitments), long-term contracts (in conjunction with the broader network of institutions and rules that constitute the legal system) do provide people with enough confidence in the consequences of their actions to facilitate intentional agency. In a similar vein, money is a social institution that both serves to facilitate economic calculation and also enables people to deal with the vagaries of an uncertain future by providing them with the liquidity required to deal with unforeseen obligations and opportunities (Runde 1993:388-93, Lawson 1998: 357-362, McKenna and 
Zannoni 2000-2001; cf Boettke and Prychitko 1998:xxi; O’Driscoll and Rizzo 1996:106, Rizzo 1996:xxvi-xxviii).

Critical realists elaborate on the above by arguing that a satisfactory understanding of the relationship between social structures (such as the social institutions just mentioned) and human agency requires that it be conceptualized as an inherently 'tensed' process: at any given moment in time, social structures pre-date and so condition current human agency, which agency subsequently leads either to the reproduction or the transformation of those structures (Archer 1995:65-92, 154-158, Sztompka 1993:199-201, 215-219, 224-229). To express the idea in terms familiar to Austrians, one might say that the interaction between structure and agency is an intrinsically historical process and as such must be conceptualised as occurring not in logical but in real historical time (Shackle 1958, O'Driscoll and Rizzo 1996:52-70, Rizzo 2000).

The starting point for understanding the significance of historical time for the relationship between social structure and human agency is the observation that all human activity takes place within the context provided by a set of pre-existing social structures. At any particular moment people confront social structures that are pre-formed in the sense that they are the product, not of their actions in the present, but of actions undertaken in the past. The starkest example of this is the fact that every person is born into a world of pre-existing social structures. These social structures are bequeathed 'ready made' to the current generation of actors, impinging involuntaristically upon the latter and confronting them a reality that is objective in the (moderate) sense that it is ontologically irreducible to their current subjective beliefs and actions (Layder 1997:9-10, 19-23, 28, 108, 112, 116, 165-166, 246, Sayer 2000:18, 35, 58-61). As Shackle ([1972] 1992:122) has put it, 'We cannot choose the present: it is too late. The present is unique ... and [already] determined' whereas 'choice requires rival possibilities.' Hence, according to critical realism, pre-existing social structures, inherited 'already determined' from the past, are ontologically distinct from the practices of actors in the present. This is significant because the fact that antecedent social structures pre-exist and are therefore ontologically irreducible to the current exercise of human agency implies that social structure is not simply the voluntaristic creation of human agency. Critical realists express this point by describing such structures as intransitive.

It is worth emphasizing at this point in the argument that while critical realists claim that there exist historically given social structures which are objective in the sense that they ontologically distinct from the current activities of agents, they do not reify those structures by denying their ultimate dependence on human agency. Intransitivity does not entail reification. Indeed, for critical realists activity-dependence is the defining characteristic of social structures and, far from denying the importance of human action in this respect, critical realists take care to specify precisely whose activities accounts for the existence of the social structures that are in place at any particular moment in time (Archer 1995:66, 72, 141-54). There are two aspects to this. First, critical realists readily acknowledge that historically given social structures are the product of human action. However, as we have seen, critical realists wish to emphasize that their activity-dependence is past tense; the structures in question are the product of actions undertaken in the past, possibly by actors long since dead, not in the present, and as a result are ontologically irreducible 
to current agency (in the present tense, so to speak). Second, critical realists also accept that while the historically given social structures extant at a particular moment in time are the result of actions undertaken in the past, their continued existence depends upon current human agency. Critical realists endorse Menger's claim that 'Each generation in every society has as its calling the evaluation and revision of received institutions' (Menger [1883] 1985:223-224; quoted in Beaulier and Boettke 2000:5, also see Mises, 1949:4647, quoted in Boettke and Storr 2000:21-22). However, as has already been explained, current human agency is informed and so made possible by pre-existing social structure. Furthermore, for reasons that will be elaborated in greater detail below, at any particular moment in time both the incentives that people have to strive either to preserve or change the structures which initially confront them, and also the distribution of the resources required to act on those incentives, are themselves embodied in the antecedent social structures as an historically given product of actions undertaken in the past. What this shows, critical realists contend, is that the human agency essential for the (continued) existence of social structure is itself dependent in a variety of ways upon (antecedent) social structure.

It is this mutual dependence between social structure and human agency that leads critical realists to describe them as being recursively related over historical time. More specifically, because current human agency takes place within the context provided by pre-existing social structures, and is itself dependent upon them, the relationship between social structure and human agency is best thought of as one in which current agency reproduces or transforms (pre-existing) social structures rather than (voluntaristically) creates them out of nothing (Archer 1995:71-72, 137-141, Lawson 1997:168-170). According to this transformational model of social activity, as it is called, pre-existing social structures both facilitate and constrain current human agency. Historically given social structures are a prerequisite for human intentional agency. For instance, activities such as speaking and writing, setting a university examination paper, and drawing up and enforcing contracts, are made possible by pre-existing social structures such as (respectively) rules of grammar, student-teacher relationships and the legal system. However, social structures do not simply facilitate human agency; they also constrain it. As Lachmann (1971:141) has put it, 'Institutions are at the same time instruments of, and constraints upon, human action.' For, as critical realists see things, the fact that social structure pre-exists and is therefore ontologically irreducible to current human agency implies that it enjoys a measure of autonomy from and influence over the latter (Archer 1995:137-139). Someone who wants to communicate effectively in Britain has to speak English. A person who insists on speaking Spanish, say, will not be understood. Merely wishing that things were different, or acting as if they were so, will not make it so. This is not necessarily because of awkwardness or intransigence on the part of the person's British interlocutors. Rather, it reflects the fact that while the rules of English grammar facilitate successful communication in Great Britain, they also compel one to speak English if one does indeed wish to communicate. However much the indigenous population might wish to help a visitor to Britain by speaking Spanish, they are unlikely to be able to do so because, thanks to the activities of the parents and teachers who educated them in the past, they were taught not Spanish but English. ${ }^{10}$ 
Social structure can thus be seen to make a difference to the way in which actors behave in the sense that the existence of a particular set of social structures (rules of grammar, for example) militates in favour of certain actions being undertaken (speaking English). For critical realists, this capacity to 'make a difference' (in this case to the behaviour of socio-economic actors) is the hallmark of causal efficacy. Social structure, conceptualised as pre-existing and therefore as enjoying a degree of autonomy from current agency can thus be seen to exert its own, sui generis causal influence on current social activity (Archer 1995:139, 147-148, 176, Lawson 1997:31-32, 57-58, Lewis 2000:251-252). What the example described in the previous paragraph illustrates is that there are social structures (such as the language which succeeding generations of people have been taught in a particular country, say) that cannot be altered immediately, even if all relevant parties agree that it is desirable to do so. Such social-structures are the consequences of past actions and, consequently, they are not attributable or reducible to the contemporary actions of agents, who quite literally inherit them. The fact that ultimately, with sufficient time and effort, succeeding generations of agents can alter inherited social structures is not at issue; the point is that, until the (possibly quite lengthy) process of change is completed, the inherited structures in question will continue to condition people's behaviour and so exert an irreducible causal influence over the course of events in the socio-economic world (Archer 1995:76-79, 85, 1998:77-78, 2000:466-469).

Critical realists conceptualise the causal efficacy of social structure in terms of an Aristotelian framework that (Bhaskar 1989:34). The paradigm of the Aristotelian approach is a sculptor. A sculptor produces works of art using the raw materials and tools available to him. The sculptor is the efficient cause - the prime mover or driving force-of this artistic activity. Nonetheless, while the material upon which the sculptor works clearly does not initiate activity (it does not sculpt itself of its own accord) and hence does not qualify as an efficient cause, it does affect the final outcome by influencing the sculptor's actions. Different types of material lend themselves to different types of sculpture and may as a result induce the sculptor to employ different tools and techniques and also to pursue different goals. Thus, the material makes a difference to the sculptor's actions, thereby exerting a causal influence over the ensuing outcome. Hence, the medium in which the sculptor works is described as a material cause of that outcome.

Critical realists regard the behaviour of the sculptor as the exemplar of social action in general. Just as a sculptor fashions a product out of the raw materials and tools available to him, so social actors produce their actions out of pre-existing social structure. Like the medium in which the sculptor works, pre-existing social structure lacks the capacity to initiate activity and to makes things happen of its own volition. It is indeed the case that people are the only efficient causes or prime-movers in society. Nevertheless, social structure does affect the course of events in the social world by influencing the actions that people choose to undertake (Archer 1995:195-201, 2000:465, Lawson 1997:187-188). The language example discussed above has already provided one illustration of how this occurs, and we shall consider others below. And by influencing the people's actions, pre-existing social structure makes a difference to and hence exerts a (material) causal influence over social life (Lewis 2000:263-265). However, this does not mean that the behaviour of actors is determined by social structure. For example, while a person who is in Britain and who 
wishes to communicate with other people will have to use the pre-existing rules of English grammar in order to produce intelligible speech acts, those rules do not determine what (s)he says or writes. The possibility also remains open that the person in question may be a taciturn character who chooses not to communicate at all. What this goes to show is that, while critical realism regards social structure as being causally efficacious, it does not reduce human agency to a mere epiphenomenon of social structure (Archer 1995:195-196, Layder 1997:22, 111-112, 200-202, Porpora 1998:346-347).

Additional insight into the causal efficacy of social structure can be gleaned by examining in greater depth the way in which social structure and human agency come into contact with one another. Two observations are particularly significant in this regard. First, as critical realists see it, society is typically structured along hierarchical lines in the sense that different people have different rights and obligations. For instance, landlords are obliged to ensure that the accommodation they provide meets certain safety standards, in return for which it is a landlord's prerogative to insist that tenants pay the rent on time and keep the property clean and tidy. Secondly, these rights and obligations typically exist independently of the particular individuals who happen to be landlords and tenants at any specific point in time. New tenants usually have the same rights and responsibilities as their predecessors. Critical realists contend that these two observations can be explained once it is recognized that social structure is constituted in large measure by a set of positions, each of which is associated with certain responsibilities and privileges that exist independently of the particular individual who occupies the position at a given moment in time. And it is through the occupancy of these positions by specific individuals - and more specifically via the conditioning of the subsequent behaviour of the incumbents by the rights, obligations and (as we shall see) interests and resources which accompany the positions-that social structure and agency are brought together.

It is possible to elaborate on the above by noting that the practices routinely followed by the occupants of such positions tend to be directed towards the occupants of other positions. For example, the rights and obligations of landlords are oriented towards, and defined in terms of, their interactions with tenants. Critical realists infer from this observation that social structure is highly relational in nature. Two types of relation are distinguished. Two entities are internally related if they are constituted by their relationship to one another. What it is to be a landlord, say, is at least partly defined by the relations that obtain between landlords and tenants (Lawson 1997:64, Sayer 2000:13). External relations occur when neither of the relata is constituted by the relationship in which it stands to the other. An example of an external relationship would be that between two strangers who pass each other on the street. While abstract ontological arguments of the sort employed by critical realists yield no a priori reason to suppose that one type of relation will be more widespread than the other, the prevalence of examples such as landlords and tenants, teachers and students, and bosses and workers suggests ex posteriori that social life does indeed appear to be highly internally related. Thus, like Austrians such as Boettke, (1989:76, 1990a:10-12, 15-22; also see Lavoie 1994: 56-8) critical realists reject those atomistic accounts of society which hold that it is populated by socially isolated Robinson Crusoes whose attributes are completely independent of the relations into which they enter with one another. 
For critical realists, then, social structure is most appropriately conceptualized as a nexus of often internally-related positions, each of which is associated with a corresponding set of rights and obligations and is occupied by an individual actor. These positions tend also to be associated with vested interests which, like the social structures themselves, constitute an objective reality that endows their occupants with reasons or incentives to pursue particular goals (Lawson 1997:264, 1999a:47, Porpora 1998:352-353, cf Boettke 1996:33, Boettke and Prychitko 1998:xiii, xxii). Antecedent social structures also impact upon current activity because, at any particular instant in time, the material and cultural resources required to prosecute particular courses of action (wealth, power, status, access to credit and the like) are distributed unequally between the various positions (along class, gender and racial lines, for example) (Layder 1997:80-81, 122-123). Depending on their location in these social hierarchies, then, people are endowed with an historically given array of resources, which in turn constitutes an ontologically irreducible influence on their current ability to further their interests (Lawson 1997:257, Porpora 1998:349-352). The conclusion of this line of reasoning, as critical realists understand it, is that antecedent social structures, and the distribution of vested interests and resources they embody, comprise the material context in which agents must act. Given that such structures are external to and autonomous from the current cohort of agents, they exert an irreducible causal influence on current activity.

Needless to say, critical realism stops short of a reductive materialism in which human subjectivity and action is no more than a reflection of pre-existent circumstances. Critical realists do not subscribe to the view that social structures act behind the backs of agents or that people are the mere carriers of material social structure. It is noteworthy in this regard that the fact that critical realists draw an ontological distinction between actors and social structure enables them to argue that the two possess rather different properties from one another. The significance of the ontological distinction in this context arises from the fact that it enables critical realists to claim without tension or contradiction that intentionality and the capacity to initiate activity characterise people without anthropomorphically attributing such properties to social structure. While social structures have their own distinctive property of material causality, they are neither conscious decision-making entities nor 'prime movers' that initiate activity and subordinate actors to the dictates of some structural imperative (Bhaskar 1989:35, Archer 1995:195-196, 198, Layder 1997:20, 100-101). On the contrary, as we have seen, critical realists argue that social structures are material (not efficient) causes which influence the course of socio-economic affairs only by the way their condition people's choice of action. ${ }^{11}$ Consequently, critical realists can speak of the causal impact that pre-existing material circumstances exert on socio-economic events without denying either the mediating role of people's interpretations (and hence the necessity of a hermeneutic moment in social science) ${ }^{12}$ or the possibility that people may respond to their circumstances in an innovative way, and therefore without making any deterministic claims about the connection between people's material circumstances and their actions. While interests always provide presumptive grounds for action, different individuals may not reach the same interpretation of given material circumstances, leading them to have different (and possibly even mistaken) views of where their interests actually lie. Furthermore, even if agents do have similar ideas of their interests, they may come to different conclusions about how best to pursue them. In particular, critical realists fully acknowledge 
that some people may display entrepreneurial flair and creatively devise new strategies for deploying (historically given) resources so as to achieve their desired goals. Moreover, it is even conceivable that, for a variety of reasons, people may act against their interests. For all of these reasons, critical realists contend that while the pre-existing pattern of interests and resources influences people and motivates them to act in certain ways, it does not uniquely determine their actions. But, to repeat, what critical realists do claim is that pre-constituted social structure, together with the associated distribution of vested interests and resources, has a potentially important impact on people's actions and therefore on the course of events in the socio-economic world, and that as a result ought not to be excluded from attempts to explain socio-economic events of interest. Stated thus, it seems hard to see why anyone would object to the critical realist position.

Overall, then, according to the perspective outlined here, society is to be understood as an intrinsically dynamic process of interaction between pre-existing social structures and current human agency, taking place in historical time. Although (as we have seen) social structures are a necessary condition for individual acts, it is only through (the totality of) the actions of individuals that any social structure endures over time. Social structures should never be regarded as permanently fixed — they should never be reified—because, given their dependency on (potentially creative and so transformative) human agency, the scope for change always remains. Hence, both society in general, and specific social institutions such as the market, must be understood as inherently dynamic processes in which change occurs not just as a result of exogenous shocks but is also endogenously generated as an integral part of social life (Lawson 1997:34-35, 170-171, 187-188, Layder 1997:81-82). ${ }^{13}$

For critical realists, then, ' $[\mathrm{T}] \mathrm{h}$. future ... is forged in the present, hammered out of past inheritance by current innovation' (Archer, 1988: xxvi). Pre-existing social structures, the deposit or residue of actions undertaken in the past, constitute the environment in which current action takes place. As we have seen, these historically given structures condition (but do not determine) the behaviour of socio-economic actors in the present by laying down an initial distribution of resources and vested interests. The (reproduced or transformed) set of social structures that emerges as the outcome of this process in turn forms the context in which the next round of social activities occurs. This account of the nature of socio-economic world would seem to contain many claims that Austrians such as Boettke would readily endorse: the portrayal of socio-economic life as an ongoing process, occurring in historical time; the importance accorded to genuine human choice and creativity; the emphasis on the role of social institutions in informing and so facilitating intentional human agency; and the avoidance of an atomistic model of man. On issues of socio-economic ontology, then, there would appear to be a good deal of common ground between critical realists and Austrians like Boettke. ${ }^{14}$

The model of explanation which arises from the critical realist picture of socio-economic life resembles that adopted by Austrians like Boettke in holding that explaining some socioeconomic phenomenon of interest consists in giving an abstract, usually discursive and always fallible account of its causes. Social events of interest must therefore be understood as the result of the causal interplay over historical time between (antecedent) social structure and (subsequent) human agency. More specifically, explanation proceeds first of all by identifying the practices responsible for phenomenon under investigation, before then going 
on to uncover the social structures which make those practices possible, along with any unconscious psychological factors which motivate them (Lawson 1997:56-58, 191-271). ${ }^{15}$

Of course, the fact that critical realists maintain that the most appropriate way to explain socio-economic phenomenon of interest is to give discursive accounts of their causes leaves critical realism somewhat at odds with the orthodox approach, according to which explanation in economics proceeds by deducing explananda as the equilibrium outcomes of formal, rational choice models. Like Boettke, critical realists attempt to justify their preferred causal model of explanation on the grounds that it is better suited to the nature of the socio-economic material under investigation than the mathematical models so beloved of orthodox economists. It is possible to elaborate on the line of reasoning by which critical realists reach this conclusion by noting that, according to critical realists, the various mathematical techniques and substantive assumptions utilised by orthodox economists reflect a long-standing commitment to deductivism. By 'deductivism' is meant a methodology which dictates that socio-economic phenomena should be analysed or 'modelled' in terms of theoretical results deduced from sets of axioms and assumptions of the form, 'Whenever these conditions, then that outcome (or distribution of outcomes)'. For critical realists, the use of a deductivist methodology is analytic to orthodox economics (Lawson 1997:86-107, 69-85, 1999a:223-233). However, critical realists maintain that this deductivist approach suffers from a number of drawbacks where the analysis of socio-economic world is concerned. For one thing, while regularities between (sets of) actualities of the form 'Whenever these conditions, then that (set or spread of) outcome(s)' are central to deductivism, (as we have already seen) ex posteriori observation reveals the socio-economic world to be an open system in which such regularities are conspicuous by their absence. The paucity of regularities displaying the strictness presupposed by orthodox economics leads critical realists to be extremely sceptical about the usefulness of such models for socio-economic analysis (Lawson 1997:70-71).

This scepticism is heightened by the fact that because socio-economic reality is open and at least in part holistic, the construction of closed-system models almost invariably requires the distortion of aspects of the socio-economic world. In order to ensure the deducibility of theoretical results, it is necessary to make a number of 'closure assumptions' that eliminate various possible sources of indeterminacy from the model-economy under investigation. First, deducibility requires that socio-economic agents are modelled as if their behaviour is determined by their preferences and the constraints they face. The standard model of rational choice exemplifies this modeling strategy. Agents are assumed to face a given means-ends framework that yields a single rational course of action. Questions of interpretation - of divining the meaning of prices and events and of deciding upon their significance - are foreclosed. Hence, the orthodoxy's commitment to deductivism leaves it with an impoverished notion of choice because, as critical realists see it, actions that are no more than a mechanical, automaton-like response to external circumstances, and which are devoid of spontaneity, imagination, drive, and so on, can hardly be said to be have been 'chosen'. Second, deductivism also requires that the actions of individual agents translate into a determinate outcome at the aggregate level. This can be guaranteed if it is assumed that the socio-economic world is atomistic, so that the actions of different agents combine mechanically to produce an aggregate outcome that is no more than the additive sum of 
their individual behaviour. However, if (as critical realists argue) that the socio-economic world is highly internally related, then models which presuppose that it is atomistic ignore a potentially important aspect of socio-economic reality (Lawson 1997:78-81, 98-102, 185-186).

For critical realists, then, the orthodox approach's neglect of the openness and internal relationality of the socio-economic world implies that it provides a highly distorted account of socio-economic reality. The dearth of stable closures in socio-economic life, taken together with the capacity of models constructed along deductivist lines to do justice neither to the reality of human choice nor to the wholistic aspects of the socio-economic world, leads critical realists to conclude with Boettke that the applicability of orthodox economic models to the socio-economic world is distinctly limited (Lawson 1997:1920, 108-133, 282, 2001b:76-79). The fact that orthodox economics has persisted with a methodology that is so unsuited to its subject-matter contrasts sharply with the way in which critical realists and Austrians place a premium on methods which have been tailored to suit the nature of the socio-economic world. The neglect of ontological issues displayed by mainstream economics leads critical realists to concur with Boettke that orthodox economics is not realist enough and that the (epistemological) goal of generating knowledge about the socio-economic world would be well-served by a shift of resources in the discipline of economics away from formal mathematical modeling towards a more widespread use of discursively constructed theories (Lawson 1997:xii-xiii, 1999b:270274).

\section{Critical Realism, Austrianism and the Material Embeddedness of Socio-Economic Activity}

There is much, then, on which critical realists and Austrians like Boettke would agree. Notably, so far as the ontology of the socio-economic world is concerned, advocates of the two approaches agree on the need to reject both the orthodoxy's under-socialised conception of man as an isolated, automaton-like atom and also over-socialised accounts according to which people are the mere playthings of over-arching, deterministic social forces. Both Austrians and critical realists seek a middle way that portrays socio-economic actors as socially embedded creatures whose (often creative) actions are both constrained and enabled by the social context in which they are situated (Boettke 1989:76-77, 1990a:13-14, 18-22, Boettke and Storr 2000:7-9, 18, 21-23).

So far, so much agreement. However, the two approaches part company on the issue of the precise nature of the middle ground between voluntarism and determinism in social theory. The vantage point provided by critical realism suggests that the phenomenologicallyinformed view of social activity to which modern Austrians like Boettke subscribe, while constituting a much more sophisticated form of methodological individualism than that espoused by orthodox economists, is not elaborate enough to do justice to the full richness of the historically given social structures in which current socio-economic activity is embedded. Boettke readily acknowledges that current activity takes place in the context provided by meanings handed down from the past (Boettke 1990a:20, 1990b:71, Boettke and Storr 2000:15-16). However, according to the critical realist account outlined above, the past's 
legacy to the present comprises more than just webs of intersubjectively agreed meanings. Historically given social structures also have a material or, in Forstater's (1997:161, 164165, 2001:214-215) felicitous phrase, 'transsubjective' component, encompassing features such as the distribution of vested interests and resources.

The ontological irreducibility of the material dimension of social structure to intersubjectively agreed meanings is driven home by a consideration of questions such as the following. First, if meanings are intersubjectively agreed, then whose interpretations are to count in the negotiations through which agreement in reached (Samuels, Medema and Schmid 1997:154-168, 184, 192 n. 27, 319, Samuels 2001:279-283)? Put slightly differently, if it is indeed the case, as scholars who have elaborated on the pheneomenological approach have suggested,${ }^{16}$ that the economy can fruitfully be viewed as a conversation in which economic agents attempt to persuade one another of the merits of their interpretation of events, the question arises of whose voice will be heard in such conversations? A second, related question centres on the issue of what motivates people to promote particular interpretations of events, institutions, and so on in the hope that they will become common, intersubjectively agreed currency. The key point is that it is difficult to see how satisfactory answers to these questions can be devised without referring to material aspects of social structure that are transsubjective or ontologically irreducible to shared meanings. A satisfactory answer to the question of who will have access to the dialogues in which shared meaning are established and, of the participants, whose influence will be the greatest, is likely to require reference to the way in which people's location in the social structures gives (or denies) them the resources (wealth, power, status, and the like) to impose their preferred meanings on others. As interpretative sociologists Berger and Luckmann (1966:126-127, 139) acknowledge, '[T] he success of particular conceptual machineries is related to the power possessed by those who operate them ... [H] who has the bigger stick has the better chance of imposing his definitions ... Those who occupy the decisive power positions are ready to use their power to impose ... definitions of reality. ${ }^{17}$ Likewise, an explanation of why particular individuals are motivated to promote certain interpretations may well turn on an account of how doing so furthers their interests as laid down by pre-existing social structure. And if it is indeed the case, as this line of argument suggests, that answering questions such as those just mentioned requires a consideration of the distribution of incentives and resources embodied in antecedent social structure, then it is hard to see how they can be satisfactorily answered within a metaphysics which confines itself to intersubjectively agreed meanings (whether in the past or the present). As Berger and Luckmann (1966:137) concede:

'These considerations imply that there will always be a social-structural base for competition between rival definitions of reality and that the outcome of the rivalry will be affected, if not always determined outright, by the development of this base.'

Just as Austrians such as Boettke $(1997: 25,1998: 175,182)$ argue that not all aspects of socio-economic life are reducible to mathematical formulae and quantitative data-to be is not simply to be the value of a variable-so in a similar vein critical realists argue that the material aspects of socio-economic life are irreducible to people's interpretations thereof. There is not, and never can be, a social tabula rasa in which interpersonal negotiations over meaning are conducted. On the contrary, negotiations over shared meanings take place within the context provided by sets of material social structures that condition 
(without determining) which interpretations and meanings, favouring whose interests, will be established. ${ }^{18}$

What this line of reasoning suggests, more generally, is that the 'working out' (Samuels 1989a) of the allocation of resources through the market process is shaped and channeled, not just by intersubjectively agreed meanings, but also by the distribution of material resources such as money, power and other mechanisms of social control embedded in inherited social structures. The latter pre-structure the interaction of economic agents, influencing (though not determining) whose preferences are to count and what weights they are accorded, and so condition the precise nature of the spontaneous order which emerges as the outcome of the market process (Lawson 1997:165, 171, Layder 1997:168). ${ }^{19}$ In turn, as the transformational model of social activity emphasizes, the current (inter)action of economic agents leads either to the reproduction or transformation of those structures, which subsequently form the backdrop for the next round of activity.

If it is indeed the case that at any given moment in time the process by which order emerges in the socio-economic world is itself structured by the distribution of vested interests and resources embedded in (pre-existing) social structures, then accounts which neglect such material, social structural considerations ignore a set of factors which may exert an important influence on the course of socio-economic life and which are therefore potentially of great explanatory importance (Layder 1997: 190-202, 246-251; Lewis and Runde 2001:210-212). The danger for Austrians such as Boettke is that, in basing their account of the socio-economic world on the category of intersubjectively agreed meanings, they run the risk of committing themselves to a restricted metaphysics that denies them conceptual purchase on the aforementioned non-hermeneutic dimensions of social structure. What is required to avoid this potential pitfall is an explicit commitment to a more elaborate metaphysics that allows social scientists explicitly to conceptualise the material social-structural influences on socio-economic life as well as intersubjective factors. It is just such a metaphysics that critical realism purports to provide. In doing so, critical realists seek to avoid 'the reductiveness of all schemes that seek to limit and impoverish a complex reality in the name of interpretation' (quoted in Forstater 2001: 214).

\section{Conclusion}

There is a good deal both in Boettke's critique of orthodox economics and also in his blueprint for an alternative approach to economic analysis that critical realists would warmly endorse. Likewise, I hope to have made a persuasive case that the methodological position adopted by critical realists is one with which Austrians should, on the whole, feel comfortable. That is not to say that there is complete conformity between the two approaches. Perhaps most notably, the account of the ontology of the socio-economic world offered by critical realism suggests that if Austrians such as Boettke adhere strictly to their official intersubjectivist metaphysics (according to which the basic building blocks of socio-economic reality are intersubjectively agreed meanings), then they will be in danger of leaving themselves unable to theorise the (material) causal impact which transsubjective social structures exert on socio-economic affairs. 
Of course, critical realists readily admit that there may be occasions when intersubjective meanings exert a greater influence than the material aspects of social structures over the course of socio-economic affairs. And by eschewing the atomistic picture of economic man utilised by orthodox economics, critical realism leaves conceptual space for such a possibility. However, as critical realists see things, the question of whether or not intersubjective influences are in fact important in any particular instance cannot be determined in advance but can only be established ex posteriori through concrete research. ${ }^{20}$ The danger for Austrians such as Boettke is that by adopting an official or explicit methodology which places so much emphasis on intersubjective meanings, they run the risk of pre-judging the issue of the importance of the latter and therefore of offering a one-sided and so misleading analysis of the phenomenon under investigation. The critical realist metaphysics, in contrast, leaves room for material social structures as well as intersubjective meanings and is therefore able to accommodate intersubjective influences without running the risk of over-emphasising their significance.

The qualification inserted in the first paragraph of this conclusion-'If Austrians such as Boettke adhere strictly to their official intersubjectivist metaphysics'-is significant because, as Samuels (1989b:57, 66) has observed, the commitment to (a sophisticated, phenomenologically-informed) individualism that is usually found in Austrians' explicit methodological pronouncements is not always mirrored in their practical research, which on occasions invokes the causal efficacy of social-structural factors. ${ }^{21,22}$ What critical realists would hope to do is to encourage Austrians such as Boettke to make an explicit commitment to an ontology which includes the category of transsubjective social structures, and which acknowledges their (material) causal efficacy, so that it can be applied in a more consistent and systematic fashion.

Of course, if Austrians do move towards the explicit adoption of something like the approach advocated by critical realists, according to which events of interest are best thought of as the product of a causal nexus comprising both the (efficient) causal agency of human actors and also the (material) causality of social structures, then they would be subscribing to a position that sits rather uneasily under the heading of methodological individualism. Rather, given that social events of interest would be explained in terms of the causal interplay between social structure and human agency, the term methodological interactionism might be a more appropriate description. This provides a stark illustration of the veracity of Boettke's (1996:33) claim that the incorporation into Austrian economics of recent developments in the philosophy and methodology of the social sciences (such as critical realism) 'will not be benign in terms of the self-understanding of the Austrian social-scientific project.'

I would like to conclude by emphasising that intellectual trade between critical realists and Austrians is a two-way process that is to the advantage of both critical realists and Austrians. Critical realists readily acknowledge that they have utilized and benefited from Austrian ideas in developing their own approach, most notably their analyses of the problem of social order (Fleetwood 1995, 1996), the informational role of prices (Sayer 1995) and the role of entrepreneurship in economic and social change. I hope that this paper will succeed in persuading Austrians that they too can benefit from an acquaintance with critical 
realism, and that as a result it will help to entice others to join what promises to be an enjoyable and fruitful conversation between the two groups.

\section{Acknowledgments}

I am very grateful to Peter Boettke, Steve Fleetwood, two anonymous referees and participants in seminars at the International Association for Critical Realism Annual Conference (Roskilde University, Denmark 2001), Lancaster University and Cambridge University for comments on earlier versions of this paper. The usual disclaimer applies.

\section{Notes}

1. The Times Higher Education Supplement, 25th March, 1994. Quoted in Lawson (1997, p. xii).

2. See Boettke $(1996,1997,1998)$.

3. See Hausman (1998) and Mayer (1998). Heilbroner (1998) provides a more sympathetic, heterodox response. Boettke's rejoinder to these commentaries is to be found in his 1998 paper in Critical Review.

4. Landmark contributions to this tradition include the works of Mises (1949) and Kirzner (1973) on entrepreneurship, Hayek $(1948,1978)$ on competition as a rivalrous process of discovery, Lachmann $(1971,1977)$ on the subjectivism of plans and the role of social institutions, O’Driscoll and Rizzo (1996) on time and ignorance, and Hayek again (1973) on rules, tacit knowledge and the notion of spontaneous order.

5. 'The first thing that should be said [about "true," non-atomistic individualism],' Hayek ([1945] 1948b: 6) writes, "is that it is primarily a theory of society, an attempt to understand the forces which determine the social life of man ... This fact should by itself be sufficient to refute the silliest of the common misunderstandings: the belief that individualism postulates (or bases its arguments on the assumption of) the existence of isolated or self-contained individuals, instead of starting from men whose whole nature and character is determined by their existence in society.' For an elaboration of this point, see Boettke (1989, 1990a), Prychitko ([1989-1990] 1995), Lavoie (1994), Madison (1990, 1994), Fleetwood (1996:743) and Caldwell (2001:548-551).

6. This is the so-called genetic-causal approach to economic methodology.

7. It is important to emphasise that critical realists readily acknowledge that, because it is impossible to comprehend the entirety of something as complex as socio-economic world in one glance, the use of some theoretical framework is in indispensable prerequisite for any attempt to understand some feature of socio-economic life. However, it does not follow from this that attempts to understand the socio-economic world must necessarily employ convenient fictions, that is to say theories and models which are based on assumptions which are descriptively false. Such a claim ignores the distinction between abstraction and idealisation (Runde 1996:17-21, Lawson 1997:108-33, 227-37). Abstraction is a process of focusing on particular aspects of some (concrete) phenomenon, with the aim of individuating or picking out particular features while ignoring others, which are (momentarily) left out of focus and relegated to the periphery of our attention. Abstract reasoning thus entails bracketing features of the phenomenon under investigation rather than denying their very existence. Idealization, in contrast, involves the ascription of features to an object that it does not in fact possess, that is, features that are false when predicated of it. Thus, theorists who use idealization invoke fictions, objects that exist only in the realm of ideas. Critical realists contend that while abstraction is indeed indispensable for understanding socio-economic phenomena of interest, idealisation (and the convenient fictions to which it gives rise) is encouraged more by the demands of mathematical tractability than by its utility in yielding insights into socio-economic life. (For a case study which illustrates this line of argument in a context of interest to Austrians, see Runde 2002.)

8. Further examples of methodologically realist pronouncements, and accordingly of common ground with critical realism, abound in the literature on Austrian economics. 'To engage in causal explanation,' Cowan and Rizzo (1996:290) write, 'is to assert the reality of the causes.' Cowan (1994:67) expands on this point as follows: 'Within the genetic-causal approach, the goal is to understand the economic system as a causal process, so genetic causal explanations must treat causes, namely desires and beliefs, as real, not simply 
as instrumental entities. If desires and beliefs are real, then ignoring, for example, the informational and computational limits of agents cannot lead to understanding the phenomenon in terms of its causes. The desires and beliefs implicit in an analysis that admits of no restrictions on agents' mental abilities are not the real causes of individual decisions.' There is a striking similarity between Cowan's comments and the critical realist contention that 'no genuine attempt at causal explanation can invoke as causes theoretical entities that have no existence other than in the minds and discourse of scientific investigators ... [f]or such entities cannot be aspects of real situations and are therefore ineligible as candidate causes' (Runde 1998:159). In a similar, methodologically realist vein, Kirzner (2000:4-10) criticizes (what he sees as) the orthodoxy's instrumentalist use of general equilibrium theory, arguing that it is methodologically legitimate to demand of economic theory that it 'realistically offer a plausible explanation of how, from any given initial set of nonequilibrium conditions, equilibrating conditions, equilibrating tendencies might be expected to be set into motion in the first place' (pp. 4-5). Similar critical realist arguments are to be found, for example, in Lawson's (1997:89-91, 108-12, 2001a) critique of orthodox economics on the grounds that, 'Instead of attempting to consider the world in which we live the [orthodox] theory project . . basically examines the logical possibilities of "worlds" [or equilibria] we have no reason to suppose could ever come about' (2001a:10 n. 3).

9. The term 'metaphysics' is used here in a non-pejorative sense to denote the set of philosophical categories in terms of which the ontology of the socio-economic world is expressed and analysed (Harré 1988:100, Butchvarov 1995:489).

10. A similar argument emphasising the importance of the importance of historical time, and in particular the way that the social structures that are the residue of past actions impact upon current behaviour can be found in Boettke and Subrick's (2001:12-3) analysis of economic reform in Russia: 'Early proponents of shock therapy overlooked this basic point: the political feasibility of reform was constrained by the past ... The reforms failed to acknowledge that the newly freed countries were not tabula rasa. They were countries that had residents who held beliefs about the world and the structure of society ... That is, history matters. The social structure that had evolved while under socialism cannot be discarded overnight. There are costs to adopting a new mental framework. One must learn how to interact with one another anew when socialism fell. People are not naturally born to trust one another. Institutions have evolved to overcome this problem of trust. Unfortunately, there were few instances of this in the former Soviet Union. As a result, the burden of history left reforming governments in a particularly difficult situation.'

11. This should go some way to allaying the concerns of Austrians like Boettke (1990a:19, 1990b:61, 1996:35) and Lavoie (1994:56) that acknowledging the causal efficacy of social structure would entail an illegitimate ascription of purposefulness and decision-making ability to social structure.

12. On the necessity of a hermeneutic dimension in social science, see Lawson (1997:34-35, 200-201, 223-225) and Sayer (2000:17-18).

13. A conception of socio-economic order, inspired by Hayek and elaborated along critical realist lines, that is compatible with the account of socio-economic life outlined here is to be found in Fleetwood (1996). Significantly, the account of order in question makes use neither of the concept of equilibrium nor of the related notion of equilibrating tendencies. Thus, critical realists side with Austrians such as Boettke, Horwitz and Prychitko (1994) and Vaughn (1999), and against Kirzner (1992:4-6, 41-44, 2000:49-50), in maintaining that abandoning the notions of equilibrium and of equilibrating tendencies does not lead inevitably to nihilism.

14. The fact that critical realists and Austrians would find much to applaud in each other's characterization of the socio-economic world should not, however, to taken to indicate that there is total agreement between the two camps on ontological issues. The devil is in the details and, as the next section of the paper will reveal, there are subtle but potentially important differences between the accounts of the structure-agency relationship to which the two approaches subscribe, centred on the precise ontological status accorded to social structure.

15. More extensive discussions of the critical realist metaphysics and of the explanatory framework to which it gives rise are to be found in Archer (1995:165-344) and Lawson (1997:157-271).

16. See, for example, Boettke (1990b:63), Lavoie (1987, 1990, 1991, 1995:392-397), McCloskey (1994:313, 367-378), and McCloskey and Klamer (1994).

17. In a similar vein, Samuels, Medema and Schmid (1997:319) contend in their discussion of Kenneth Boulding's (1956) book, The Image, that '[T]he operative image is in part a function of the structure of power which determines both what/whose images are relevant and which will be selected.' 
18. For an acknowledgement that this line of reasoning has some merit, see Boettke (1990a:16) and Beaulier and Boettke (2000).

19. For similar points, see Samuels (1989a:532-538, 1989b:57-60, 65-68, 1999, 2000).

20. For illustrations of how an acknowledgement of the material dimension of social structure matters for understanding a topic of considerable interest to Austrians, namely knowledge-creation in firms, see Hardy, Phillips and Lawrence (1998) and Lewis (2003).

21. Compare, for instance, the claim that 'Austrians ... 'overcome[.] the pitfalls of positing either an over- or undersocialised view of the individual by maintaining that their behaviour affected by, influenced by, even directed by social structures and relations but not determined by them' (Boettke and Storr 2000:9; 2000:2123, Boettke 1997:25, Boettke and Prychitko 1998:xiii), which appears to imply an acknowledgement of the possibility that social structure has a (material) causal impact on socio-economic affairs, with the denial of the causal efficacy of social structure implied by Cowan's (1994:63) claim that, 'Market outcomes are thus causally reducible to the desires and beliefs of agents'.

22. Perhaps most notably, Fleetwood (1995) has argued that Hayek was able to reach a satisfactory resolution of the problem of social order only after moving beyond an exclusive focus on the hermeneutic dimension of social structures and acknowledging their material, non-hermeneutic aspects as well. For additional studies which support the claim that Hayek ultimately abandoned methodological individualism and acknowledged the material dimension of social structure, see Sciabarra (1995) and Runde (2001). For a similar study of Lachmann, see Lewis and Runde (2003).

\section{References}

Archer, M. S. (1995) Realist Social Theory: The Morphogenetic Approach. Cambridge: Cambridge University Press.

Archer, M. S. (1996) Culture and Agency: The Place of Culture in Social Theory. Cambridge: Cambridge University Press.

Archer, M. S. (1998) "Social Theory and Analysis of Society.” In: May, T. and Williams, M. (Eds.) Knowing the Social World. Buckingham: Open University Press.

Archer, M. S. (2000) "For Structure: Its Reality, properties and Powers. A Reply to Anthony King.” The Sociological Review, 48: 464-472.

Arrow, K.J. and Hahn, F. H. (1971) General Competitive Analysis. Amsterdam: North-Holland.

Beaulier, S. and Boettke, P. J. (2000) "Of Norms, Rules and Markets: A Comment on Samuels.” Mimeo, George Mason University.

Berger, P. L. and Luckmann, T. (1966) The Social Construction of Reality: A Treatise in the Sociology of Knowledge. London: Penguin Books.

Bhaskar, R. (1989) The Possibility of Naturalism: A Philosophical Critique of the Contemporary Human Sciences, 2nd edition. Hemel Hempstead: Harvester Wheatsheaf.

Boettke, P. J. (1989) "Evolution and Economics: Austrians as Institutionalists." Research in the History of Economic Thought and Methodology, 6: 73-89.

Boettke, P. J. (1990a) "Individuals and Institutions." Critical Review, 4: 10-26.

Boettke, P. J. (1990b) "Interpretative Reasoning and the Study of Social Life." In: Prychitko (Ed., 1995).

Boettke, P. J. (1994) "Alternative Paths Forward for Austrian Economics." In: Boettke (Ed., 1994).

Boettke, P. J. (Ed., 1994) The Elgar Companion to Austrian Economics. Aldershot: Edward Elgar.

Boettke, P. J. (1996) "What is Wrong with Neoclassical Economics (and What is Still Wrong with Austrian Economics)?” In: Foldvary, F.E. (Ed.) Beyond Neoclassical Economics: Heterodox Approaches to Economic Theory. Cheltenham: Edward Elgar.

Boettke, P. J. (1997) "Where did Economics Go Wrong? Modern Economics as a Flight From Reality." Critical Review, 11: 11-64.

Boettke, P. J. (1998) "Formalism and Contemporary Economics: A Reply to Hausman, Heilbroner and Mayer." Critical Review, 12: 173-186. 
Boettke, P. J. (1999) "Introduction: Which Enlightenment, Whose Liberalism? Hayek's Research Programme for Understanding the Liberal Society.” In: Boettke, P. (Ed.) The Legacy of Friedrich von Hayek. Vol. I: Politics. Cheltenham: Edward Elgar.

Boettke, P. J., Horwitz, S. and Prychitko, D. (1994) "Beyond Equilibrium Economics: Reflections on the Uniqueness of the Austrian Tradition.” In: Boettke, P. and Prychitko, D. L. (Eds.) The Market Process: Essays in Contemporary Austrian Economics. Aldershot: Edward Elgar.

Boettke, P. J. and Prychitko, D. L. (1998) "Introduction: Varieties of Market Process Theory.” In: Boettke, P. J. and Prychitko, D. L. (Eds.) Market Process Theories, Vol. I: Classical and Neoclassical. Cheltenham: Edward Elgar.

Boettke, P. J. and Storr, V. H. (2000) "Post Classical Political Economy: Polity, Society and Economy in Weber, Mises and Hayek." Mimeo, George Mason University.

Boettke, P. J. and Subrick, J. R. (2001) "From the Philosophy of the Mind to the Philosophy of the Market." Paper presented at the 2001 ASSA Meetings in New Orleans.

Buchanan, J. M. ([1969] 1979) "Is Economics the Science of Choice?” In: Buchanan, J. M. (Ed., 1979), What Should Economists Do? Indianapolis: Liberty Fund.

Butchvarov, P. (1995) “Metaphysics.” In: Audi, R. (Ed.) The Cambridge Dictionary of Philosophy. Cambridge: Cambridge University Press.

Caldwell, B. (2001) "Hodgson on Hayek: A Critique.” Cambridge Journal of Economics, 25: 539-553.

Cowan, R. (1994) "Causation and Genetic Causation in Economic Theory." In: Boettke, P. J. (Ed., 1994).

Cowan, R. and Rizzo, M. J. (1996) “The Genetic-Causal Tradition and Modern Economic Theory.” Kyklos, 49: 273-317.

Ebeling, R. M. (1986) “Towards a Hermeneutical Economics: Expectations, Prices, and the Role of Interpretation in a Theory of the Market Process.” In: Kirzner, I. M. (Ed.) Subjectivism, Intelligibility and Economic Understanding: Essays in Honour of Ludwig M. Lachmann on his Eightieth Birthday. New York: New York University Press.

Ebeling, R. M. (1987) “Cooperation in Anonymity.” Critical Review, 1: 50-61.

Ebeling, R. M. (1990) "What is a Price? Explanation and Understanding." In: Lavoie, D. (Ed.) Economics and Hermeneutics. London and New York: Routledge.

Fleetwood, S. (1995) Hayek's Political Economy: The Socio-Economics of Order. London and New York: Routledge.

Fleetwood, S. (1996) “Order without Equilibrium: A Critical Realist Interpretation of Hayek's Notion of Spontaneous Order." Cambridge Journal of Economics, 20: 729-747.

Forstater, M. (1997) “Adolph Lowe and the Austrians.” Advances in Austrian Economics, 4: 157-173.

Forstater, M. (2001) "Phenomenological and Interpretive-Structural Approaches to Economics and Sociology: Schutzian Themes in Adolph Lowe's Political Economics." The Review of Austrian Economics, 14: $209-218$.

Geanakoplos, J. (1987) “Arrow-Debreu Model of General Equilibrium.” In: Eatwell, J. Milgate, M. and Newman, P. (Eds.) The New Palgrave: A Dictionary of Economics, Vol. I. London: Macmillan.

Hahn, F. H. (1984) Equilibrium and Macroeconomics. Oxford: Basil Blackwell.

Hardy, C., Phillips, N., and Lawrence, T. (1998) "Distinguishing Trust and Power in Interorganizational Relations: Forms and Façades of Trust.” In: Lane, C. and Bachmann, R. (Eds.) Trust Within and Between Organizations: Conceptual Issues and Empirical Applications. Oxford: Oxford University Press.

Harré, H. R. (1988) The Philosophies of Science. Oxford: Oxford University Press.

Hausman, D. M. (1998) “The Faults of Formalism and the Magic of Markets.” Critical Review, 12: 127-138.

Hayek, F. A. ([1937] 1948) "Economics and Knowledge.” In: Hayek, F. A. (Ed., 1948).

Hayek, F. A. ([1945] 1948a) "The Use of Knowledge in Society." In: Hayek, F. A. (Ed., 1948).

Hayek, F. A. ([1945] 1948b) "Individualism: True and False." In: Hayek, F. A. (Ed., 1948).

Hayek, F. A. (1948) “The Meaning of Competition.” In: Hayek, F. A. (Ed., 1948).

Hayek, F. A. (1948) Individualism and Economic Order. Chicago: University of Chicago Press.

Hayek, F. A. (1973) Law, Legislation and Liberty, Vol. I: Rules and Order. Chicago: University of Chicago Press.

Hayek, F. A. (1978) “Competition as a Discovery Procedure.” In Hayek, F. A. (Ed.), New Studies in Philosophy,

Politics, Economics and the History of Ideas. Chicago: University of Chicago Press.

Heilbroner, R. (1998) “The Self-Deception of Economics.” Critical Review, 12: 139-150.

Kirzner, I. M. (1973) Competition and Entrepreneurship. Chicago: University of Chicago Press. 
Kirzner, I. M. (1992) The Meaning of the Market Process: Essays in the Development of Modern Austrian Economics. London and New York: Routledge.

Kirzner, I. M. (2000) The Driving Force of the Market: Essays in Austrian Economics. London and New York: Routledge.

Lachmann, L.M. (1971) he Legacy of Max Weber. Berkeley: Glendessary Press.

Lachmann, L.M. (1977) Capital, Expectations and the Market Process. Kansas City: Sheed, Andrews and McMeel.

Lavoie, D. (1987) "The Accounting of Interpretations and the Interpretation of Accounts: The Communicative Function of 'The Language of Business'.” Accounting, Organizations and Society, 12: 579-604.

Lavoie, D. (1990) "Understanding Differently: Hermeneutics and the Spontaneous Order of Communicative Processes.” Annual Supplement to History of Political Economy, 22: 359-377.

Lavoie, D. (1991) "The Discovery and Interpretation of Profit Opportunities: Culture and the Kirznerian Entrepreneur." In: Berger, B. (Ed.), The Culture of Entrepreneurship. San Francisco: Institute for Contemporary Studies Press.

Lavoie, D. (1994) “The Interpretive Turn.” In: Boettke, P. J. (Ed., 1994).

Lavoie, D. (1995) "The 'Objectivity' of Scholarship and the Ideal of the University." Advances in Austrian Economics, 2B: 371-403.

Lawson, T. (1997) Economics and Reality. London and New York: Routledge.

Lawson, T. (1998) "Clarifying and Developing the Economics and Reality Project: Closed and Open Systems, Deductivism, Prediction, and Teaching." Review of Social Economy, 56: 356-375.

Lawson, T. (1999a). "Critical Issues in Economics as Realist Social Theory.” In: Fleetwood, S. (Ed., 1999), Critical Realism in Economics: Development and Debate. London and New York: Routledge.

Lawson, T. (1999b) "What has Realism Got to do with It?" Economics and Philosophy, 15: 269-282.

Lawson, T. (2001a) 'Two Responses to the Failings of Modern Economics: The Instrumentalist and the Realist." Review of Population and Social Policy, 10: 1-27. Tokyo: National Institute for Population and Social Security Research.

Lawson, T. (2001a) "Mathematical Formalism in Economics: What Really is the Problem?" In Arestis, P., Desai, M. and Dow, S. (Eds.) Methodology, Microeconomics and Keynes: Essays in Honour of Vicky Chick. London and New York: Routledge.

Layder, D. (1997) Modern Social Theory: Key Debates and New Directions. London: UCL Press.

Lewis, P. A. (2000) "Realism, Causality and the Problem of Social Structure." Journal for the Theory of Social Behaviour, 30: 249-268.

Lewis, P. A. (2003) “The Social Embeddedness of Organisational Activity: Beyond Granovetter.” Paper Presented at the European Group for Organisational Studies Annual Colloquium, Copenhagen Business School.

Lewis, P. A. and Runde, J. H. (2001) “Intersubjectivity in Economics: A Critical Realist Perspective.” In: Fullbrook, E. (Ed.), Intersubjectivity in Economics: Agents and Structures. London and New York: Routledge.

Lewis, P. A. and Runde, J. H. (2003) "Lachmann on the Possibility of Socio-Economic Order: A View from Cambridge.' Mimeo, Cambridge University.

Madison, G. B. (1990) "How Individualistic is Methodological Individualism?” Critical Review, 4: 41-60.

Madison, G.B. (1994) "Phenomenology and Economics.” In Boettke, P. J. (Ed., 1994).

Mayer, H. ([1932] 1994) “The Cognitive Value of Functional Theories of Price.” In: Kirzner, I. M. (Ed.), Classics in Austrian Economics: A Sampling in the History of a Tradition. Vol. II: The Interwar Period. London: William Pickering.

Mayer, T. (1998) “Boettke's Austrian Critique of Mainstream Economics: An Empiricist's Response." Critical Review, 12: 151-171.

McCloskey, D. N. (1994) Knowledge and Persuasion in Economics. Cambridge: Cambridge University Press.

McCloskey, D. N. (1994) “One Quarter of GDP is Persuasion.” American Economic Review, 84: 191-195.

McKenna, E. J. and Zannoni, D. C. (2000-2001) "Post Keynesian Economics and Nihilism.” Journal of Post Keynesian Economics, 23: 331-347.

Menger, C. ([1883] 1985) Investigations into the Method of the Social Sciences with Special Reference to Economics. New York: New York University Press.

Milgrom, P. R. and Roberts, J. (1992) Economics, Organization and Management. Englewood Cliffs, NJ: Prentice Hall.

Mises, L. von (1949) Human Action. New Haven, CT: Yale University Press. 
O’Driscoll, G.P. and Rizzo, M. J. (1996) The Economics of Time and Ignorance, 2nd edn. London and New York: Routledge.

Porpora, D. V. (1998) “Four Concepts of Social Structure.” In: Archer, M. S., Bhaskar, R. Collier, A. Lawson, T. and Norrie, A. (Eds., 1998) Critical Realism: Essential Readings. London and New York: Routledge.

Prychitko, D. L. ([1989-1990] 1995) “Methodological Individualism and the Austrian School.” In: Prychitko, D. L. (Ed., 1995).

Prychitko, D. L. (Ed., 1995) Individuals, Institutions, Interpretations: Hermeneutics Applied to Economics. Aldershot: Avebury.

Rizzo, M. J. (1996) "Introduction: Time and Ignorance After Ten Years.” In: O’Driscoll and Rizzo (Eds., 1996).

Rizzo, M. J. (2000) "Real Time and Relative Indeterminacy in Economic Theory.” In: Baert, P. J. N. (Ed.) Time in Contemporary Intellectual Thought. Amsterdam: Elsevier Science B. V.

Runde, J. H. (1996) "Abstraction, Idealisation and Economic Theory.” In: Arestis, P., Palma, G. and Sawyer, M. (Eds.) Markets, Unemployment and Economic Theory: Essays in Honour of Geoff Harcourt, Vol. II. London and New York: Routledge.

Runde, J. H. (1998) “Assessing Causal Economic Explanations.” Oxford Economic Papers, 50: 151-172.

Runde, J. H. (2001) "Bringing Social Structure Back into Economics: On Critical Realism and Hayek's Scientism Essay." Review of Austrian Economics, 14: 5-24.

Runde, J. H. (2002) "Information, Knowledge and Agency: The Information-Theoretic Approach and the Austrians." Review of Social Economy, 60: 183-208.

Samuels, W. J. (1989a) "Determinate Solutions and Valuational Processes: Overcoming the Foreclosure of Process. "Journal of Post Keynesian Economics, 11: 531-546.

Samuels, W. J. (1989b) “Austrian and Institutional Economics: Some Common Elements.” Research in the History of Economic Thought and Methodology, 6: 53-71.

Samuels, W. J. (1999) "Hayek from the Perspective of an Institutionalist Historian of Economic Thought: An Interpretive Essay.” Journal Des Economistes et des Etudes Humaines, 9: 279-290.

Samuels, W. J. (2000) “An Essay on the Unmagic of Norms and Rules and of Markets.” Journal Des Economistes et des Etudes Humaines, 10: 391-397.

Samuels, W. J. (2001) "The Political-Economic Logic of World Governance." Review of Social Economy, 54: 273-284.

Samuels, W. J., Medema, S. G., and Schmid, A. A. (1997) The Economy as a Process of Valuation. Cheltenham: Edward Elgar.

Sayer, A. (1995). Radical Political Economy: A Critique. Oxford: Blackwell.

Sayer, A. (2000) Realism and Social Science. London: SAGE.

Sciabarra, C. M. (1995) Marx, Hayek and Utopia. Albany: State University of New York Press.

Shackle, G. L. S. (1958) Time in Economics. Amsterdam: North-Holland Publishing Company.

Shackle, G. L. S. (1966) The Nature of Economic Thought: Selected Papers 1955-1964. Cambridge: Cambridge University Press.

Shackle, G. L. S. (1969) Decision, Order and Time in Human Affairs, 2nd edn. Cambridge: Cambridge University Press.

Shackle, G. L. S. ([1972] 1992) Epistemics and Economics: A Critique of Economic Doctrines. New Brunswick and London: Transaction Publishers.

Sztompka, P. (1993) The Sociology of Social Change. Oxford: Blackwell.

Vaughn, K. I. (1994) Austrian Economics in America: The Migration of a Tradition. Cambridge: Cambridge University Press.

Vaughn, K. I. (1999) "Hayek's Implicit Economics: Rules and the Problem of Order.” Review of Austrian Economics, 128-144. 